International Journal of Small Business and Entrepreneurship Research

Vol.4, No.6 pp.1-22, November 2016

Published by European Centre for Research Training and Development UK (www.eajournals.org)

PERSPECTIVE OF SUSTAINABILITY MANAGEMENT IN MICRO KPRS SHARIA SUBSIDIZED PROGRAM

\author{
Willy Arafah \\ (Trisakti University), \\ M. Budianto \\ (Local Public Work, Curup, Bengkulu)
}

\begin{abstract}
Baitul Maal Wattami (BMT) Dana Insani is a Micro finance Institutions located in the region Gunung Kidul, DI Yogyakarta Province. The Microfinance Institutions use legal foundations from the Cooperative and operate using Islamic Financial system was founded by local community since 2002 to bridge the limitations of access to finance for MBR having a productive business in the region. Based Ministry Regulation No. 06 of 2006 about the construction / improvement of self-help housing through credit / micro financing facilities housing subsidies, the government provides subsidies for MBR will construct or improve their homes independently. The implementation of programs involving the participation of MPLs was followed by BMT DI. BMT DI participation as implementing Sharia Micro KPRS program subsidized for three phases showed an increased realization of significant. This indicates a good response from the Islamic MFLs in implementing the program. A case study was conducted to determine the extent of the capabilities of the BMT DI, MBR characteristics and acceptance of the terms and the prospect of sustainability of such programs on BMT DI. To answer these questions, research carried out by using quantitative methods, reinforced with qualitative data. The analysis showed that the successful management of BMT DI based on the principle of Cooperative built from the bottom and use the principles of Islamic finance is a preference Muslims. The realization of Islamic micro KPRS program subsidized BMT DI experiencing an increasing trend, although implementation using collateral and there are some MBR demands that their costs may be cheaper. Their demand that followed the availability of land in the region to make BMT DI has great prospects for continued management of the program. There are factors that cause ongoing management of the program, namely the trend decline in the total number of borrowers who apply for loans at BMT DI and program implementation depends on factors subsidies. The use of the principle of trust and collateral on the MFI can expand the range of services the provision of credit to the MBR.It is advisable to investigate further the strategy in the development of MFIs with the principles of trust, but able to serve MBR widely.In addition, the need to develop mechanisms and institutions a subsidy, so that the benefits better targeted.It is suggested that there is the role of local government in the implementation of Sharia Micro Subsidized KPRS program, so as to improve the quality of the environment.
\end{abstract}

KEYWORDS: Prospects for Sustainability, KPRS Syariah Micro Subsidized, MFI and MBR

\title{
BACKGROUND OF RESEARCH
}

Micro credit is intended not only as a source of financing for small and medium enterprises only, with the enactment of the Ministry of Housing No. 06 of 2006, on the Development/

ISSN: 2052-6377(Print), ISSN: 2052-6385(Online) 
Governmental Housing Repair through Credit/Microfinance with Support Facility Subsidy for Housing, The government attempted to create a source of funding that can be accessed MBR to build or improve their homes independently. To implement the program Micro KPRS need the participation of Micro Finance Institutions (MFIs) or Non-Bank Financial Institutions (NBFIs) which can be mentioned Koperasi, Lembaga Perkreditan Desa, Badan Keswadayaan Masyarakat, and Pegadaian, both of which operate using conventional and Islamic systems, which will provide the loan principal and delivering self-help housing subsidies to the MBR.

Approach to financing low-income housing through micro credit is a relatively new breakthrough, since it was first introduced in 2006. However, based on the plan that has been set by the government, it is a serious attempt to improve the construction/home improvement MBR independently.In the Medium Term Development Plan (Plan) National housing sector from 2004-2009, the government has set as many as 3.6 million housing units that will be financed through the micro-credit program.Data obtained from the Ministry of Housing, said that the realization of KPRS Micro has been channeled through various MFIs/NBFIs is Rp. 1,821,177,064. (2006), Rp, 83,475,909,779 (2007) and Rp, 251,271,936,500. (Per July 31, 2008), which has been channeled through various MFIs/NBFIs in Indonesia, both of which use Islamic and conventional operating system.

Among the various MFIs/NBFIs have begun to implement the program since 2006 is Baitul Mal Wattamwil (BMT) Dana Insani, is located in District Wonosari Gunung Kidul, Yogyakarta Province.BMT DI is a publisher of financial institutions issuing the legal status of Cooperative which is in operation using the principles of Islamic finance, where BMT DI in the implementation of the program is a partner of the BMT Inti, which gives access to financing or partnership for MFIs/Cooperative else will move in the housing sector.Implementation of Sharia Micro KPRS subsidized program managed BMT DI showed a rising trend is quite good,that occurred during the last three years.Realization of the program to the first phase amounted to only 11 units, has increased to 21 units in the second stage and then increased to 90 units in the third stage.Based on this, the researcher are trying to learn more about the implementation of the programs managed by BMT DI, which is expected to provide additional knowledge for writers and observers of the housing problem,particularly on financing low-income housing is done through a pattern of microcredit as well as to contribute to the relevant stakeholders in the area for future development.

\section{Formulation of the Problem}

Participation of BMT DI as an MFI that implement KPRS Sharia Micro program Subsidizedin facilitating access to finance for MBR,indicate that during the three stages of implementation it does an there increasing realization that significant, which indicates an ability for the management of the credit.

Based on the formulation of the problem, the research will be conducted to seek answers to the question:

1. How does the ability institutional in terms of:

a. Financial Aspect

b. Institutional Aspects

2. How characteristic MBR doing construction/home improvement and their acceptance of the existing requirements(affordable $\&$ acceptable). 
Published by European Centre for Research Training and Development UK (www.eajournals.org)

3. What are the prospects of sustainability management KPRS program Islamic micro subsidized administered by the BMT Dana Insani?

\section{LITERATURE REVIEW}

The credit word comes from the Latin credera the meaning is trust.The person or institution that provides credit to the person/entity who took the credit to believe that the credit will be paid back on time. In the word of the credit there is value time difference between administration and the returns are going to do.Mahmud (1986) states that in brief the meaning of credit in economics is a delay in payment.Microcredit has various definitions, Grameen Banking (2003) define as the development of micro-credit loans to small entrepreneurs who are too weak to their qualifications to be able to access credit from traditional banks.In the meeting of the World Summit on Micro Credit, 1997, microcredit is defined as program lending small amounts to poor people to the business activities to increase revenue,granting loans to take care of themselves and their families. While microfinance institutions of formal, semi-formal, and informal financial institutions that conduct financial services to microentrepreneurs low-income communities (Krisnamurti, 2002).

Micro finance institutions have special characters corresponding to their constituents, such as: 1) Consisting of various forms of financial services, particularly savings and loans; 2) geared to serve low-income communities; and 3) use the system as well as a simple procedure (Chotim and Hand, 2001).Based on the shape, Wijono (2005) divides the MFI into three groups, namely:

a. Formal institutions such as rural banks and cooperatives.

b. Semi-formal institutions such as non-governmental organizations.

c. Informal sources such as moneylenders or social gathering.

From the various definitions that exist seen equation that essentially micro-credit is a form of financing that do microfinance institutions to weak economic community with the loan amount is relatively small as well as through a simple process that can intermediated gap financing sources between MBR on banks that have requirements that can't be met by the weak economic community.

\section{Institutionalism Approach}

This type of approach prioritizes the creation of financial institutions to serve clients that are not served or not served by the formal financial system (commercial banks). The purpose of this approach is to achieve institutional independence through achieving financial independence, a broad range and depth and influence positive clients with the main focus is the success of financial institutions and which used to be measured by the progress of the institution in achieving financial independence. The Institutionalisms argue that microfinance is a financial mastery, namely the creation of the financial system that is sustainable (sustainability) are different for the poor. The Institutionalisms reject any kind of subsidization, because they cling to financial independence.

ISSN: 2052-6377(Print), ISSN: 2052-6385(Online) 


\section{Welfare Approach}

This approach emphasizes the direct poverty reduction through lending.Robinson (2001: 22) states that with this approach the loan granted to poor borrowers, especially with interest rates below the market with the intention to touch the poor,especially the poorest of the poor. Furthermore, Arsyad also mentioned that based on research conducted Robinson (2001) that these two approaches basically have the same role in the development of institutional microfinance,but the welfare approach (welfarist) seems more appropriate for people who are the poorest of the poor.Overall the institutions that have successfully implemented a welfare approach can only meet a fraction demand for microfinance,because most institutions with this approach (subsidized loans) do not have a sustainability.

Instead institutionalism approach has been proven to provide financial services, including both loans and savings, for those clients with low incomes on a large scale, while maintaining the level of profitability and sustainability (Robinson in Arsyad, 2008).Based on the publications issued by CGAP through electronic media, that there are ten kinds of principles in microfinance, namely:

1. Poor people need a variety of financial services, not just loans.As with many other people, poor people need a variety of financial services that are convenient, flexible, and reasonable pricing.Depending on their circumstances, poor people need not only credit but also savings, money transfers, and insurance.

2. Microfinance is a powerful instrument to fight poverty.Access to sustainable financial services enables the poor to increase income, build assets, and reduce their vulnerability to external shocks. Microfinance allows low-income households to move beyond the struggle to survive from day to day towards planning for the future, investing in better nutrition, improved living conditions, as well as the improvement of health and education of children.

3. Microfinance means building financial systems that serve the poor.Poor people constitute the vast majority of the population in most developing countries.However, the overwhelming number of poor continue to lack access to basic financial services.In many countries, microfinance continues to be seen as a marginal sector and primarily a development concern for donors, governments, and investors with social responsibility.In order to achieve the full potential of microfinance in reaching a large number of the poor, microfinance should become an integral part of the financial sector.

4. Financial sustainability is necessary, in order to be able to reach poor people in large numbers.Most poor people are not able to access financial services due to lack of strong financial intermediaries. Building a financially sustainable institutions is not an end in itself.Financially sustainable institutions is the only way to reach significant scale and impact far beyond anything that could be funded by donors.Sustainable is this ability allows the continued operation of microfinance providers and the provision of financial services continuously for the poor.Achieving financial sustainability means reducing transaction costs, offering better products and services that suit the needs of customers, and finding new ways to reach the poor who do not get service from the bank.

5. Microfinance is it about building permanent local financial institutions.Building financial systems for the poor means building sound domestic financial intermediaries that can provide financial services to poor people permanently.Such institutions should be able to mobilize and recycle domestic savings, extend credit, and provide a variety of services.Dependence on funding from donors and governments, including government- 
Published by European Centre for Research Training and Development UK (www.eajournals.org)

financed development banks will gradually be reduced when various local financial institutions and private capital markets were growing up.

6. Microcredit is not always the answer. Microcredit is not appropriate for everyone or every situation. The destitute and hungry who have no income or means of repayment, need other forms of support before they can make use of loans.In many cases, small grants, infrastructure improvements, employment and training programs, and other non-financial services is probably more appropriate tools for poverty reduction. Where possible, such nonfinancial services should be coupled with building savings.

7. Restrictions on interest rates could hurt the poor's access to financial services.It costs more if it gives many small loans rather than providing a few large loans. Unless micro lenders can charge interest rates far above the average bank lending rates, they will not be able to cover their costs, and their growth and sustainability will be limited due to supply of subsidized funding scarce and uncertain. When governments regulate interest rates, they usually set them at levels too low to permit sustainable microcredit.At the same time, micro lenders should not pass on operational inefficiencies to clients in the form of prices (interest rates and other fees) were much higher than expected.

8. Government's role is as an enabler, not a direct provider of financial services. National governments play an important role in shaping a supportive policy environment that encourages the development of financial services while protecting poor people's savings. The key steps that a government can do for microfinance are to maintain macroeconomic stability, avoid interest-rate caps, and Mendham themselves from changing market conditions with a variety of loan programs subsidized, high-delinquency and unsustainable.Governments can also support financial services for the poor by improving the business environment for entrepreneurs, combating corruption, and improving access to markets and infrastructure.In special situations, government funding for microfinance institutions are healthy and independent may be warranted when other funds are not available.

9. Donor subsidies should complement, not compete with private sector capital. Donors should use appropriate grant, lend and equity instruments on a temporary basis to build the institutional capacity of financial providers, develop supporting infrastructure (like rating agencies, credit bureaus, audit capacity, etc.), and support a variety of experimental services and products.In some cases, long-term donor subsidies may be required to reach an area with low population numbers and otherwise difficult.To be effective, donor funding must seek to integrate financial services for the poor into local financial markets; applying special expertise in project design and implementation; that financial institutions and other partners meet minimum performance standards as a condition for continued support; and the planned exit from the outset.

10. The lack of institutional and human capabilities is a key constraint.Microfinance is a specialized field that develops banking with social goals, and capacity needs to be developed at all levels, ranging from financial institutions through the regulatory and supervisory agencies as well as information systems, to government development agencies and donors.Most investments in the sector, both public and private, should focus on the development of these capacities.

11. The importance of financial and outreach transparency.Accurate information, standards, and financial and social performance information that can be compared from financial institutions that provide services to the poor is very important.Regulatory bodies and regulatory constituent banks, donors, investors, and more importantly, the poor who are 
clients of microfinance need this information in order to assess risk and the results adequately.

\section{Sustainability on Microfinance Institutions}

Arsyad (2008) states that the MFI is regarded as a financial institution that aims to provide access to finance easier for MBR, so the MFI should be able to have the ability / financial feasibility to achieve self-reliance.With their financial independence, then the MFI has the prospect to be able to continue to perform their activities as a provider of access to finance for MBR or to survive in a sustainable manner.Related to sustainable levels, (Christen et al, 1995 in Arsyad, 2008: 4) split level MFI sustainability into three categories, namely:

1. The first category is the MFI whose income derived from interest and fees, can't cover operating costs.MFIs in this category highly dependent on subsidies from donors or the government, in the form of grant assistance or loans with soft interest.

2. The second category is the MFI whose revenues can cover operating costs, but it can't cover the commercial cost of funds that can be loaned.The second category refers to the MFI interest and its fee may cover the cost of non-financial, but still relies on subsidies to a certain degree for the cost of the loaned funds.

3. The third category is the MFI is completely self-contained and can cover all the costs of financial, non-financial and risk is calculated based on the commercial value and profit.

Based on these descriptions, the sustainability of MFIs is strongly influenced by financial factors or their ability to manage their business so it can operate without reliance on subsidies.Thus, operating income and operating costs are variables that determine the sustainability assessment MFIs, where operating costs are expenses to be borne in the process of distribution of funding (loans), while operating income represents income earned on venture financing (credit) done.

Suyanto (1998) explains that the provision of funds by financial institutions can be obtained from various sources, such as loans from other parties, equity, savings and so forth. With the various sources of funding, it is certain there is a difference in the return value of each source of financing must be considered separately to obtain financing costs for the utilization of these funds.

Furthermore Suyanto (1998) also explained that funding costs are influenced by: The structure of sources of funds; interest rate/services that are paid for each source of funds; the amount of the reserve requirement needed for each source of funds; tax laws (tax regulation) as well as the location of the market where operates.

\section{Microcredit Housing}

The house is a basic need for everyone, not least for the MBR.In fulfilling the need for decent shelter, one of the constraints faced by the MBR is the issue of financing.Stringent banking regulations in lending an obstacle for some people to have access to banking.Various characteristics possessed by the MFI has created the opportunity to make MFIs as a source of financing for the MBR to be able to provide a livable dwelling.In micronote No. 26, published by USAID, "Expanding microfinance for housing, "stated thatMicrofinance for housing (MFH) is a subset of microfinance, designed to meet the housing needs of the poor and very poor, especially those without access to the banking sector or formal mortgage 
loans.Based on this description it appears that the MFI has a function of intermediation for the MBR on access to housing finance.

Bruce Ferguson (1999) mentions the characteristics of housing finance through MFIs as follows:The characteristics of micro-finance include small loan size for incremental upgrading of an existing dwelling or a new core unit, short repayment period, small or no subsidy, creative underwriting adapted to the conditions and prospects faced by low/moderate-income, technical assistance in documentation and building, and-sometimesalternate forms of title as collateral. A publication issued by Accion electronically(Accion, Insight-Developing Housing Microfinance Product in Central America, 2004), an organization engaged in assisting MFIs, that the markets in Central America did not respond to the low-income housing finance products, with constraints:

- Affordability, the cost of construction of the core housing units (including land, services and buildings) that are beyond the capability.

- Limited availability of tittles, most poor families in Latin America do not have a legal letter of ownership of their lands, consequently they can't use their homes as collateral.

- Traditional mortgages unavailable or inappropriate for microentrepreneurs, the problem income unwritten or not fixed, letter of land ownership as well as the inability to make payments has removed the long-term access for such loans.

Recognizing this, the government and NGOs put the three solutions, namely:

- $\quad$ Subsidized loans (subsidized mortgage loans), a government credit programs and other organizations to provide low-interest (subsidized).

- $\quad$ Construction of houses for the MBR (Low-income housing development), carried out the construction of low-income housing, with the use of low cost buildings and the sweat of beneficiaries.

- $\quad$ Direct-demand subsidies, a new approach that uses direct assistance (grant) from the government to stimulate the private sector in housing loans.Subsidies combined with savings and housing loans.

In the publication is also written that based on experience, of these three approaches, have shown three weaknesses:

1. Limited funding subsidy, so that only a few families and MFIs are getting funding.

2. Households that receive subsidies often less increase in loan payments.

3. In the case of housing finance / loan program, that these loans are typically determined by the level of income, none of those programs that can achieve significant scale and by definition are not sustainable.

4.

Action and other MFIs have used a different approach and have developed a technique known as micro-financing of housing. Micro-financing housing Action version is without the use of subsidies, with a sustainable approach that is designed for the needs of the MBR market.The products implement best practices developed over the years for microfinance for housing needs. The housing finance upgrading homes for poor families progressive (progressive build), including an increase in indoor conditions existing homes, room additions or completes the installation of water and electricity, in which a complete home was built in stages. 
Published by European Centre for Research Training and Development UK (www.eajournals.org)

Institutions should be more responsive to customers and develop the products offered, particularly investment in housing. The stakeholder institutions, such as donors and private investors increased the pressure on MFIs to achieve financial performance that is sustainable, because the housing finance are often larger and longer than lending to micro and have repayment rates problematic smaller, thus giving an opportunity to improve profit MFIs if it can keep expenditure on financing.

The pilot project conducted by Action in product development housing finance micro contained in the paper the report in collaboration with FAMA in Nicaragua and Integral in El Salvador, which is carried out to test the six main hypotheses related to the MFI's ability to implement microfinance housing a success, namely:

1. Housing microfinance is a more appropriate method than traditional housing finance to serve the financing needs of the MBR.

2. Micro housing finance can be integrated in the MFI without adverse impact on the quality or development of existing portfolios.

3. Officers MFIs that already exists can be trained to offer housing loans without a negative effect on their productivity.

4. MBR construction requires technical assistance, such as golden images, RAB or supervise workers, which vary for each client, so that if there is such a technical assistance component, it is something different for each client.

5. Housing micro-finance program, including the selection of a technical assistance component to guarantee the sustainability of construction and gain / profit for MFIs within a period of two years.

6. Housing micro-finance portfolio, was designed to be implemented by both the MFI, so as to achieve a scale similar to the portfolio of existing micro enterprises.

Based on the results of operations to be carried, the key lesson Action against the proposed hypothesis are:

1. Housing microfinance is a method of lending more appropriate in an appeal to serve the financing traditional financing low-income housing.MFI has reached thousands of customers who have a deficiency in collateral with the traditional focus on the capacity of repayment of the loan (repayment) and receive guarantees, in the form of goods households, insurers and inventory, where it will not be accepted at an institution other financing.

Some customers have the completeness of that needed for a traditional mortgage financing, institutions can more easily accept such collateral.

2. Housing finance can be integrated into existing micro-finance operation, without any negative impact on the quality or the growth of the portfolio and have a level of financing problems were lower compared to business loans.

3. Existing MFIs officers can be trained to offer housing loans with no negative effect on their productivity.This hypothesis is valid, if the technical components are restricted to controlling expenses and adapted to local conditions.After the training, FAMA concluded that there was no difference in productivity between officials working on two areas, namely residential and business, compared to working only in the field of business only.

The first factor is the lack of financing problems in housing loans, which means that officers with housing portfolio greater spending less time in the financing problems of his colleagues.Another factor is to closely monitor the technical evaluation during the pilot 
Published by European Centre for Research Training and Development UK (www.eajournals.org)

phase, to ensure the credit staff can use them efficiently.If there are difficulties, the institution needs to simplify the evaluation or re-use estimates.

4. MBR construction requires technical assistance, which varies for each customer. So far the results obtained do not reject the hypothesis mentioned, but it is very difficult and require expensive for institutions to provide a variety of help tailored to each customer.There is no evidence that the failure to provide the sort of advice would restrict effective funding programs.

Integral and FAMA used a different approach in aid of construction, the integral provide more detailed advice using special officers, but FAMA limit in accordance with the financial evaluation.This approach led to FAMA use of staff and existing processes, thus making borrowing more from Integral and ensure that their product provides a bigger profit.

5. Micro-financing housing, including a selection of construction assistance component, can guarantee construction quality standards and achieve sustainability/benefits for MFIs in two years. This hypothesis was tested at Integral, the survey concluded that the construction quality of construction aid did not have a visual impact on the quality of construction. Costs in this type of aid, notably by hiring extra staff, takes time to train staff and low staff efficiency is of substantial benefit to the decline of the product.

Costs incurred in technical assistance does not produce gains in terms of construction quality, but it may just be an added value for customers and provide benefits for MFIs than its competitors from the client's perspective.

However, market research revealed that the attributes of the main purposes in a competitive market is the adequacy of the loan amount and terms, the ease of the procedure and cost.Technical assistance, especially if it led to higher costs for the institution, did not seem like a major advantage for the institution.

6. Housing micro-finance portfolio, was designed to be implemented well by the MFI, so as to achieve a scale similar to the portfolio of existing micro enterprises. Both of these products is still relatively young, too fast to conclusions about this hypothesis, the results achieved so far indicate that the product housing has the potential to achieve that scale, but need to be measured throughout the year.

\section{Baitul Mal Wattamwil (BMT)}

Heri Sudarsono (2007) in his book Islamic Banks and Financial Institutions says that outline BMT has two main functions:

a. Bait al maal: Institutions that leads to the efforts of the collection and distribution of funds are non-profit, like charity, infaq, and sadaqoh.

b. Bait at tamwil: Institutions that lead to business commercial collection and distribution of funds.

From these definitions in mind that BMT can function as a social institution (non-profit) and may also have a commercial function in terms of raising funds, or lending. At first the existing BMT-BMT is formed as a self-help group that is not incorporated,founded by individuals and community groups.The subsequent development, there are many parties who are not responsible to establish an institution that calls itself BMT but only as a cover to gain from the collection of public funds.In March 1995, the chairman of the Indonesian Ulema Council (MUI), Chairman of the Association of Indonesian Muslim Intellectuals (ICMI) and the Director of Bank Muamalat Indonesia set up the Foundation's Business Incubation Small Business Indonesia (YINBUK) with the aim to improve human resources, community economy, business and finance savings and loans, with a target of micro-entrepreneurs, 
subsequently formed Small Business Incubation Centre (PINBUK) which is a working board of YINBUK, which operates on a national and provincial level. PINBUK national level is responsible for formulating and promoting the concept of BMT, design concept development of BMT, training, monitoring and evaluation of the performance of BMT, set up in cooperation with other parties, to certify the BMT, as an effort to prevent their BMT operating without official status (Holloh, 2001).

\section{Data Collection Methods and Analysis}

Assessment of the acceptance of the MBR on the existing requirements are performed using respondents in the sample of the population who have earned MBR Simple Home Loan (Paras). Determination of the number of samples or the respondent performed in stages as follows:

\section{a. Population}

Population is the whole of the set of elements that have a number of common characteristics, which consists of areas for examination.Or the population is a whole group of people, events or things that are of interest to researchers studied (Malhotra: 1996). Based on these definitions, the population in this study were all members of BMT Dana Insani participating in the program Syariah Micro KPRS Subsidized, with population that is the object of research is 122 people.

b. Samples

The sample is part of the number and characteristics possessed by this population. When large populations and researchers may not learn all that there is in the population, for example, because of limited funds, manpower and time, the research institute, and can use a sample drawn from that population. What is learned from the sample, the conclusion will be applied to the population.For that samples taken from the population should be rigorously representative (representing). According to Rahmat (1995: 82), determining the number of samples can be done by using the formula:

$$
n=\frac{N}{N \cdot(d)^{2+1}}
$$

Where:

$\mathrm{n}=$ The number of samples to be taken

$\mathrm{N}=$ Total Population

$\mathrm{d}=$ Minimal error rate $(10 \%)$

Thus the minimum required number of samples with an error rate of $10 \%$ is:

$\mathrm{n}=\frac{122}{122 \cdot(0,1)^{2}+1}$

$\mathrm{n}=55$ samples

\section{c. Mechanical Sampling}

Mechanical sampling is required to determine the sample to be used.In this study, samples were taken by 55 respondents who have the lowest income based on the data available on the BMT.Determination of respondents based on the lowest incomes is intended to describe the condition of the actual MBR.

Based on the number and criteria predefined sample, the subsequent data collection in the following way: 
Published by European Centre for Research Training and Development UK (www.eajournals.org)

1. Draw up a questionnaire (annex)

2. Filling the questionnaire by respondents

3. Process and present the data

4. Analyzing the collected data.

Table-1

Data Collection and Analysis Techniques - Acceptance of the Terms of Existing MBR

\begin{tabular}{|l|l|l|l|}
\hline \multicolumn{2}{|l|}{ DATA } & ANALYSIS \\
\hline JENIS & SOURCE & $\begin{array}{l}\text { COLLECTION } \\
\text { TECHNIQUES }\end{array}$ & \\
\hline$\bullet \quad$ Installment \\
patterns and sanctions \\
$\bullet \quad$ Collateral \\
$\bullet \quad \begin{array}{l}\text { Technical } \\
\text { Requirements }\end{array}$ & & $\begin{array}{l}\text { Respondents } \\
\text { Questionnaire }\end{array}$ & \\
\hline
\end{tabular}

\section{Prospect Analysis of Sustainability Management Program}

The data that has been processed as points 3.1 to 3.4 are then analyzed the potential and constraints, which is conducted qualitatively by subjective ratings may be using the data and study materials/literature relevant.The results are further analyzed, so that a conclusion of the ongoing prospects of program management KPRS Subsidized Micro Sharia at the BMT Dana Insani.

\section{Overview of Case Studies}

\section{MBR Characteristics}

Based on the data obtained, the characteristics of the MBR 122 people who do construction / home improvement through Sharia Micro KPRS program subsidized is as follows:

Table -2

\section{MBR Characteristics}

The Result of Secondary Data

\begin{tabular}{|l|l|l|l|}
\hline & CRITERIA & TOTAL \\
\hline A & TYPE OF WORK & RESPONDENT & PERCENT (\%) \\
\hline 1 & Entrepreneur/Trader & 59 & 48.36 \\
\hline 2 & Civil Servants/Employees & 40 & 32.79 \\
\hline 3 & Farmer & 17 & 13.93 \\
\hline 4 & Labor & 3 & 2.46 \\
\hline 5 & Other (Driver \& Retired) & 3 & 2.46 \\
\hline B & INCOME (Rp.) & & \\
\hline 1 & $<600.000$ & 21 & 17.21 \\
\hline 2 & $600.000-1.000 .000$ & 86 & 70.49 \\
\hline 3 & $1.000 .000-1.400 .000$ & 8 & 6.56 \\
\hline 4 & $1.400 .000-1.800 .000$ & 7 & 5.74 \\
\hline
\end{tabular}


International Journal of Small Business and Entrepreneurship Research

Vol.4, No.6 pp.1-22, November 2016

Published by European Centre for Research Training and Development UK (www.eajournals.org)

\begin{tabular}{|l|l|l|l|}
\hline C & EDUCATION & & \\
\hline 1 & No School & 3 & 2.46 \\
\hline 2 & Primary School and Equivalent & 18 & 14.75 \\
\hline 3 & Junior High School and Equivalent & 9 & 7.38 \\
\hline 4 & Senior High School and Equivalent & 56 & 45.90 \\
\hline 5 & Diploma/Degree & 36 & 29.51 \\
\hline D & AGE (YEARS) & & \\
\hline 1 & $<30$ & 20 & 16.39 \\
\hline 2 & $30-40$ & 63 & 51.64 \\
\hline 3 & $40-50$ & 23 & 18.85 \\
\hline 4 & $>50$ & 16 & 13.11 \\
\hline
\end{tabular}

Based on data from the MBR characteristics can be summarized:

1. MBR compositions according to the type of work areentrepreneur/trader $(48.65 \%)$; civil servants/employees (32.79\%) and Farmer (17.93\%).

2. A total of $87.70 \%$ MBR had income of less than Rp1,000,000.-, as much as $6.65 \%$ have an income between Rp1,000,000.- up to Rp1,400,000.- and there is a 5.74\% earning between Rp1,400,000.- up to Rp1,800,000.-

3. There are $24.95 \%$ were educated up to junior high school; $45.90 \%$ have high school level; and $29.50 \%$ have a diploma/degree.

4. A total of $54.64 \%$ between $30-40$ years old MBR; $18.85 \%$ are aged between $40-50$ years; $16.39 \%$ are under the age of 30 years and $13.11 \%$ over 50 years.

\section{Acceptance of Collateral}

Findings showed that 51 respondents $(92.73 \%)$ provide collateral, where as many as 32 people $(58.18 \%)$ to provide collateral in the form of proof of ownership of land or a certificate of land and 19 others $(34.55 \%)$ gave collateral in the form of a letter of motor vehicles.However, there are 4 respondents $(7.27 \%)$ which states exempted from collateral on the grounds has long been a loyal customer BMT (and ever borrow more than twice).

Table -3

The composition of respondents by collateral

Results of Primary Data Processing

\begin{tabular}{|l|l|l|l|l|l|}
\hline & \multicolumn{2}{|l|}{ Respondent Total } & Types of & \multicolumn{2}{l|}{ Respondent Total } \\
\cline { 2 - 3 } \cline { 5 - 6 } & Respondent & $\%$ & Collateral & Respondent & \% \\
\hline With Collateral & 51 & 92.73 & $\begin{array}{l}\text { Certificate of } \\
\text { Land }\end{array}$ & 18 & 32.73 \\
\cline { 5 - 6 } & & & Land Title & 14 & 25.45 \\
\cline { 5 - 6 } & & $\begin{array}{l}\text { Vehicle Carr } \\
\text { Ownership }\end{array}$ & 19 & 34.55 \\
\hline Without Collateral & 4 & 7.27 & - & 4 & 7.27 \\
\hline
\end{tabular}

Opinions of respondents to the problem of collateral applied by BMT are as follows: 
Published by European Centre for Research Training and Development UK (www.eajournals.org)

Table -4

Respondents Revenues on Collaterals

Results of Primary Data Processing

\begin{tabular}{|l|l|l|l|l|l|}
\hline No. & Criteria & \multirow{2}{*}{$\begin{array}{l}\text { Total } \\
(\text { respondent })\end{array}$} & $\begin{array}{l}\text { MBR Suitability } \\
\text { Against Collateral }\end{array}$ & $\begin{array}{l}\text { Which are } \\
\text { Desired }\end{array}$ \\
\cline { 4 - 5 } & & Yes & No & \\
\hline 1 & With collateral & 51 & $\begin{array}{l}22 \text { respondent } \\
(40.00 \%)\end{array}$ & $\begin{array}{l}29 \text { respondent } \\
(52.73 \%)\end{array}$ & $\begin{array}{l}\text { Delete/ } \\
\text { Lighter }\end{array}$ \\
\hline 2 & Without Collateral & 4 & 4 respondent & - & - \\
\hline
\end{tabular}

A total of $52.73 \%$ of respondents wanted the elimination or relief on collateral applied.

Acceptance of the Installment Pattern and Sanctions

A total of 43 respondents (78.18\%) stated that in accordance with the system of monthly installments and as much as 12 respondents $(21.82 \%)$ want more installment system, where as many as 5 of whom (9.09\%) want a daily installment and 3 other (5.34\%) with a weekly system.

Table - 5

Respondent Income on Installment System

Results of Primary Data Processing

\begin{tabular}{|c|c|c|c|c|}
\hline \multirow[t]{2}{*}{$\begin{array}{l}\text { Installment } \\
\text { System }\end{array}$} & \multicolumn{2}{|c|}{$\begin{array}{l}\text { Conformity to the Installment } \\
\text { System }\end{array}$} & \multicolumn{2}{|c|}{ Installment Desired } \\
\hline & Yes & No & System & Total \\
\hline \multirow[t]{2}{*}{ Monthly } & \multirow[t]{2}{*}{$\begin{array}{l}47 \text { respondent } \\
(85.45 \%)\end{array}$} & \multirow[t]{2}{*}{$\begin{array}{l}8 \quad \text { respondent } \\
(14.55 \%)\end{array}$} & Daily & $\begin{array}{l}5 \quad \text { respondent } \\
(9.10 \%)\end{array}$ \\
\hline & & & Weekly & $\begin{array}{l}3 \quad \text { respondent } \\
(5.45 \%)\end{array}$ \\
\hline
\end{tabular}

Table - 6

Respondent Income over the Place of Payment

Result of Primary Data Processing

\begin{tabular}{|l|l|l|l|l|}
\hline \multirow{2}{*}{$\begin{array}{l}\text { Place } \\
\text { Payment }\end{array}$} & \multicolumn{2}{|l|}{ Total of Respondent } & \multicolumn{2}{l|}{$\begin{array}{l}\text { MBR Suitability of the Place of } \\
\text { Payment }\end{array}$} \\
\cline { 2 - 5 } & Respondent & Percent (\%) & Respondent & Percent (\%) \\
\hline Office & 39 & 70.91 & 39 & 100.00 \\
\hline Staff & 16 & 29.09 & 16 & 100.00 \\
\hline
\end{tabular}

Regarding the system of sanctions imposed by BMT DI, all respondents (100\%) agreed with the existing system.Similarly, the location of installment payments, all respondents $(100 \%)$ 
Published by European Centre for Research Training and Development UK (www.eajournals.org)

declared in accordance with their wishes, with the description of $39(70.91 \%)$ paid in the office and 16 people $(29.09 \%$ paid through BMT staff.

\section{Acceptance of Technical Requirements}

a. Plan Image and Budget Planning

Fulfillment of technical requirements that include pictures plan, the budget plan, the composition of the utilization of services of technical assistance by the MBR as well as their opinions are as follows:

Table -7

Making the Customer Technical Planning KPRS Micro Result of Primary Data Processing

\begin{tabular}{|l|l|l|l|l|l|}
\hline No. & Explanation & $\begin{array}{l}\text { Total } \\
\text { (respondent) }\end{array}$ & $\begin{array}{l}\text { Conformity of the Technical } \\
\text { Planning Costs }\end{array}$ & $\begin{array}{l}\text { Which are } \\
\text { Desired }\end{array}$ \\
\cline { 4 - 5 } & & Yes & No & \\
\hline 1. & Plan Image & 46 & $\begin{array}{l}30 \text { respondent } \\
(65.22 \%)\end{array}$ & $\begin{array}{l}16 \text { respondent } \\
(34.78 \%)\end{array}$ & Lower Cost \\
\hline 2. & Budget Planning & 51 & $\begin{array}{l}38 \text { respondent } \\
(74.51 \%)\end{array}$ & $\begin{array}{l}13 \text { respondent } \\
(25.49 \%)\end{array}$ & Lower Cost \\
\hline
\end{tabular}

It is seen that almost all respondents are still in need of assistance in the manufacture of technical requirements, but as much as $34.78 \%$ want a lower cost for the preparation of the plans and as much as $25.49 \%$ want a lower cost to manufacture RAB.

b. Building Permit (IMB) / Description Building

In making the building permit or certificate of the IMB, the cost ranges between Rp120.000, to Rp250.000,-.In the arrangement there were 31 respondents $(56.36 \%)$ who takes care of himself and 24 respondents (43.64\%) ask for help from others.Income respondents to the costs they incur are:

Table -8

Income - Preparation IMB Cost/Certificate of Building Result of Primary Data Processing

\begin{tabular}{|c|c|c|c|c|c|c|}
\hline \multirow[t]{2}{*}{ No. } & \multirow[t]{2}{*}{$\begin{array}{l}\text { IMB } \\
\text { Construction }\end{array}$} & \multicolumn{2}{|l|}{ Total } & \multicolumn{2}{|c|}{$\begin{array}{l}\text { The Suitability of The } \\
\text { Building Permit Fees }\end{array}$} & \multirow[t]{2}{*}{$\begin{array}{l}\text { Which are } \\
\text { Desired }\end{array}$} \\
\hline & & Respondent & $\begin{array}{l}\text { Percent } \\
(\%)\end{array}$ & Yes & No & \\
\hline 1. & Personally & 31 & 56.36 & \multirow{2}{*}{$\begin{array}{l}21 \\
\text { respondent } \\
(38.18 \%)\end{array}$} & \multirow{2}{*}{$\begin{array}{l}34 \\
\text { respondent } \\
(61.82 \%)\end{array}$} & \multirow{2}{*}{$\begin{array}{l}\text { There is no } \\
\text { cost or low } \\
\text { cost }\end{array}$} \\
\hline 2. & Help Others & 24 & 43.64 & & & \\
\hline
\end{tabular}

A total of 21 respondents $(38.18 \%)$ stating their costs are appropriate, while 34 respondents $(61.82 \%)$ said do not according to their wishes, and ask for their relief or waiver of the building permit fees. 
Published by European Centre for Research Training and Development UK (www.eajournals.org)

\section{Loan Repayment Rate}

Based on the interview with the manager was aware that the smooth repayment of the loan/financing made by customers during KPRS Micro is $100 \%$ (no financing uncollected).

\section{Financial Feasibility}

The Data and Assumptions Used

Data on the capital/investments in programs carried out by BMT DI are as follows:

Table -9

\section{Total KPRS Micro Financing, Subsidies and Loans Provided Principal BMT} Result of Primary Data Processing

\begin{tabular}{|l|l|l|l|l|l|}
\hline No. & Program & $\begin{array}{l}\text { The KPRS } \\
\text { Micro } \\
\text { Customer } \\
\text { (Person) }\end{array}$ & $\begin{array}{l}\text { The Value of } \\
\text { Micro KPRS } \\
\text { Program } \\
\text { (Rp) }\end{array}$ & $\begin{array}{l}\text { The } \\
\text { Subsidy } \\
\text { Value } \\
(\mathbf{R p )}\end{array}$ & $\begin{array}{l}\text { Loans Granted } \\
\text { by BMT } \\
\text { (Rp) }\end{array}$ \\
\hline 1 & Stage 1 & 11 & $179,529,000$ & $89,000,000$ & $90,529,000$ \\
\hline 2 & Stage 2 & 21 & $374,940,000$ & $181,000,000$ & $193,940,000$ \\
\hline 3 & Stage 3 & 90 & $1,655,148,000$ & $804,000,000$ & $851,148,000$ \\
\hline
\end{tabular}

Loans granted the use of a variety of funding sources, either in the form of equity capital, as well as third party capital.Based on interviews, it is known that the financing and margin of each of these sources of funding are:

- $\quad$ In 2006 \& 2007 using their own capital.

- In 2008 capital investments using their own capital and (Musharaka) of BPD Sharia.

- $\quad$ Simple House Deposits Margin 0.2 (Saras) $=0.2 \%$ /month

- Wadiah Deposit Margin 0.2\% /month (flat)

- $\quad$ Mudharobah Deposit Margin 0.5\% /month (flat)

- $\quad$ Sharia BPD margin of $1.4 \%$ /month (decline)

- $\quad$ Tenor Period Credit Micro KPRS years (48 months)

- $\quad$ KPRS Micro Credit Margin $1.5 \%$ /month (flat)

From the existing data, in the calculation of the next several assumptions as follows:

- In 2006, the funding sources used are:

- $\quad$ Saras Deposit : Rp33,000,000.00

- Wadiah Deposit : Rp57,529,000.00

- $\quad$ In 2007, the funding sources used are:

- $\quad$ Saras Deposit : Rp63,000,000.00

- Mudharobah Deposit : Rp130,940,000.00 (Profit Sharing) the composition

BMT 65:35 Sharia BPD

\section{Calculation of Revenue and Expenditure}

a. Revenue (cash inflow)

Acceptance comes from customers installments, charged with a margin rate of $1.5 \%$ per month. The amount of revenue that is: 
Published by European Centre for Research Training and Development UK (www.eajournals.org)

Table - 10

Amount of the Installment Receipts

\begin{tabular}{|c|c|c|c|c|c|}
\hline \multirow[t]{2}{*}{ No. } & \multirow[t]{2}{*}{ Program } & \multirow{2}{*}{$\begin{array}{l}\text { Amount of } \\
\text { Credit Granted } \\
\text { (Rp) }\end{array}$} & \multirow{2}{*}{$\begin{array}{l}\text { Margin } \\
\text { (\%/month) }\end{array}$} & \multicolumn{2}{|c|}{ Installment Receipts } \\
\hline & & & & (Rp/month) & (Rp/month) \\
\hline 1 & Stage 1 & $90,529,000$ & 1.5 & $3,243,956$ & $155,709,880$ \\
\hline 2 & Stage 2 & $193,940,000$ & 1.5 & $6,929,952$ & $332,637,680$ \\
\hline 3 & Stage 3 & $851,148,000$ & 1.5 & $30,499,470$ & $1,463,974,560$ \\
\hline
\end{tabular}

b. Expenditure (Cash outflow)

Expenditure in question is the amount of expenditure on the cost of financing expenses (cost of funds) and operational costs (operating cost).Funding costs are cost incurred for the use of funds from each source of funds, which consist of the cost margin and fees for results. While operating costs are the costs required for the operations of credit, the result of computation as in the following table:

\section{Margin Cost:}

Margin cost are associated cost with resource use, with the following description:

Table -11

Margin Funding Cost

\begin{tabular}{|c|c|c|c|c|c|c|c|c|c|}
\hline \multirow{2}{*}{$\begin{array}{l}\text { No } \\
\cdot\end{array}$} & \multirow{2}{*}{$\begin{array}{l}\text { Progra } \\
\text { m }\end{array}$} & \multicolumn{3}{|c|}{ SIMPANAN SARAS } & \multicolumn{4}{|c|}{ SUMBER DANA LAINNYA } & \multirow{2}{*}{$\begin{array}{l}\text { Total } \\
\text { Margin } \\
\text { Cost } \\
\text { (Rp/month } \\
\text { ) } \\
\end{array}$} \\
\hline & & $\begin{array}{l}\text { Value } \\
\text { (Rp) }\end{array}$ & $\begin{array}{l}\text { Margi } \\
\mathrm{n} \\
(\%)\end{array}$ & $\begin{array}{l}\text { Margin } \\
\text { Cost } \\
\text { (Rp/month } \\
\text { ) }\end{array}$ & $\begin{array}{l}\text { Value } \\
\text { (Rp) }\end{array}$ & $\begin{array}{l}\text { Source } \\
\text { of } \\
\text { funds }\end{array}$ & $\begin{array}{l}\text { Margi } \\
\mathrm{n}(\%)\end{array}$ & $\begin{array}{l}\text { Cost } \\
(\%)\end{array}$ & \\
\hline 1 & 2 & 3 & 4 & $5=3 \times 4$ & 6 & 7 & 8 & $\begin{array}{l}9= \\
6 \times 8\end{array}$ & $10=5+9$ \\
\hline 1 & Stage 1 & $\begin{array}{l}33,000,00 \\
0\end{array}$ & 0.20 & 66,000 & $\begin{array}{l}57,529,00 \\
0\end{array}$ & Wadiah & 0.20 & $\begin{array}{l}115,05 \\
8\end{array}$ & 181,058 \\
\hline 2 & Stage 2 & $\begin{array}{l}63,000,00 \\
0\end{array}$ & 0.20 & 126,000 & $\begin{array}{l}130,394,0 \\
00\end{array}$ & Mdrb & 0.50 & $\begin{array}{l}651,97 \\
0\end{array}$ & 777,790 \\
\hline 3 & Stage 3 & $\begin{array}{l}270,000,0 \\
00\end{array}$ & 0.20 & 540,000 & $\begin{array}{l}581,148,0 \\
00\end{array}$ & $\mathrm{BPD}$ & 1.40 & $*$ & $*$ \\
\hline
\end{tabular}

*Decline Margin

\section{Operational Cost:}

Determination of costs charged to the program KPRS Micro do with the approach to the operational costs incurred by the institution, which then assumed and charged to all existing customers, the fees charged on each customer will serve as the basis for setting the operational costs of the program KPRS Micro. 
Table - 12

Customer and Operational Cost

\begin{tabular}{|l|l|l|l|l|}
\hline No. & Years & $\begin{array}{l}\text { Institutional } \\
\text { Operating Cost } \\
(\text { Rp/month) }\end{array}$ & $\begin{array}{l}\text { Total Number } \\
\text { of Customer } \\
\text { (person) }\end{array}$ & $\begin{array}{l}\text { Fees Charged } \\
\text { (Rp/person) }\end{array}$ \\
\hline 1 & 2 & 3 & 4 & $5=3: 4$ \\
\hline 1 & 2006 & $10,698,504$ & 2,320 & 4,611 \\
\hline 2 & 2007 & $14,684,382$ & 2,300 & 6,385 \\
\hline 3 & 2008 & $15,814,217$ & 2,350 & 6,729 \\
\hline
\end{tabular}

Table - 13

Operational Costs Micro KPRS

\begin{tabular}{|l|l|l|l|l|}
\hline No. & Program & $\begin{array}{l}\text { Institutional } \\
\text { Operating Costs } \\
(\text { Rp/month) }\end{array}$ & $\begin{array}{l}\text { Total Number } \\
\text { of Customer } \\
\text { (person) }\end{array}$ & $\begin{array}{l}\text { Fees Charged } \\
\text { (Rp/person) }\end{array}$ \\
\hline 1 & 2 & 3 & 4 & $5=3: 4$ \\
\hline 1 & Stage 1 & 11 & 4,611 & 50,729 \\
\hline 2 & Stage 2 & 21 & 6.385 & 134,075 \\
\hline 3 & Stage 3 & 90 & 6,729 & 605,651 \\
\hline
\end{tabular}

\section{Profit Sharing Fees}

Based on the assumption that there is no delay in payment, then the profits obtained in stage 2 and 3 programs, BMT obliged to pay a revenue share of 35\% (assuming the ratio corresponding to the result in part 4.14.1) of profits, in proportion to the respective funds used.Calculation (Appendix 1a, 1b and 1c), the cost for the results to be incurred by BMT DI to each source of funds.

The amount of the refund of a loan from each of these sources of funds have different levels. Based on calculations (appendix) rate of return on each of these sources of funds, which is comparable to the interest rate is as follows:

$\checkmark \quad$ Returns Wadiah Savings, equivalent to the interest rate of $2.40 \%$ per year.

$\checkmark \quad$ Returns Mudharobah Savings, equivalent to the interest rate of 9.02\% per years.

$\checkmark \quad$ Returns Sharia BPD, equivalent to the interest rate $12.53 \%$ per year.

\section{Calculation of Financial Feasibility Analysis}

Financial feasibility of the implementation of the program, carried out using three analysis as follows:

a. Comparison of Benefits with Benefits to Cost Ratio (BCR)

Analysis of Benefit to Cost Ratio (BCR) is done by comparing the benefits (revenue value) obtained by the value of the expenditure.If the ratio value is greater than 1:00, the lending is feasible to do otherwise if the ratio is less than 1.00 then the loan is not feasible. BCR calculation results are: 
Published by European Centre for Research Training and Development UK (www.eajournals.org)

Table - 14

BCR Value

\begin{tabular}{|l|l|l|l|l|}
\hline No. & Program & $\begin{array}{l}\text { Income } \\
(\mathbf{R p})\end{array}$ & $\begin{array}{l}\text { Expenditure } \\
(\mathbf{R p})\end{array}$ & BCR \\
\hline 1 & 2 & 3 & 4 & $5=3: 4$ \\
\hline 1 & Stage 1 & $155,709,880$ & $101,654,616$ & 1.53 \\
\hline 2 & Stage 2 & $332,637,680$ & $237,172,150$ & 1.40 \\
\hline 3 & Stage 3 & $1,463,974,560$ & $1,191,908,888$ & 1.23 \\
\hline
\end{tabular}

b. $\quad$ The Net Present Value (NPV)

NPV method is performed to find the difference between the present value of net cash flow to the present value of an investment.An investment is said to have economic advantages, so it is feasible, if the NPV is greater than zero.Conversely, if the NPV is smaller than zero, the investment is not feasible.The formula in calculating the NPV is:

With:

$$
N P V=-I_{0}+\sum_{t=0}^{n} \frac{A_{t}}{(1+r)^{t}}
$$

Io $=$ the value of investments (outlays)

At $=$ the net cash flow in $t$ period

$r=$ Discount rate

$\mathrm{t}=$ investment period

Table - 15

\section{Net Cash Flow}

\begin{tabular}{|l|l|l|l|l|l|l|}
\hline No. & \multirow{2}{*}{ Program } & Net Cash Flow (Rp/year) \\
\cline { 3 - 7 } & & $\mathbf{0}$ & $\mathbf{1}$ & $\mathbf{2}$ & $\mathbf{3}$ & $\mathbf{4}$ \\
\hline 1 & Stage 1 & $(90,529,000)$ & $36,146,066$ & $36,146,066$ & $36,146,066$ & $36,146,066$ \\
\hline 2 & Stage 2 & $(193,394,000)$ & $72,214,882$ & $72,214,882$ & $72,214,882$ & $72,214,882$ \\
\hline 3 & Stage 3 & $(851,148,000)$ & $261,790,676$ & $275,869,938$ & $287,757,776$ & $297,795,282$ \\
\hline
\end{tabular}

\section{NPV-Program Stage 1}

The program has been obtained from the first phase of capital Saras Savings and Wadiah Savings, which has a margin of $0.20 \%$ / month or equivalent to an interest rate of $2.40 \%$ per year.

\begin{tabular}{|l|l|l|l|}
\hline Years & FV & P/F (2,4,n) & PV \\
\hline 0 & - & & $(90,529,000)$ \\
\hline 1 & $36,146,066$ & 0.9766 & $35,298,893$ \\
\hline 2 & $36,146,066$ & 0.9537 & $34,471,575$ \\
\hline 3 & $36,146,066$ & 0.9313 & $33,663,647$ \\
\hline 4 & $36,146,066$ & 0.9095 & 32874,656 \\
\hline & & & $45,779,770$ \\
\hline
\end{tabular}

The calculations show the value of the first phase of the program NPV greater than zero that is $\operatorname{Rp} 45,779,770,-$ so the investment is feasible.

\section{NPV-Program Stage 2}

NPV-Program Phase 2 Source of funds obtained from the capital Saras Saving with a margin of $0.20 \%$ per month and assuming the use Mudharobah Saving with a margin of $0.50 \%$ per

ISSN: 2052-6377(Print), ISSN: 2052-6385(Online) 
Published by European Centre for Research Training and Development UK (www.eajournals.org)

month. And a margin based on the proportion of each source of funds, then the value of the average margin is equivalent to an interest rate of $4.51 \%$ per annum.

Table - 16

NPV Program Stage 2

\begin{tabular}{|l|l|l|l|}
\hline Years & FV & P/F (4,5,n) & PV \\
\hline 0 & - & & $(193,394,000)$ \\
\hline 1 & $72,214,882$ & 0.9568 & $69,098,538$ \\
\hline 2 & $72,214,882$ & 0.9156 & $66,116,676$ \\
\hline 3 & $72,214,882$ & 0.8760 & $63,263,493$ \\
\hline 4 & $72,214,882$ & 0.8382 & $60,533,435$ \\
\hline & & & $65,618,142$ \\
\hline
\end{tabular}

The calculations show the value of the second phase program NPV is greater than zero, i.eRp65,618,142 So, the investment is feasible.

\section{NPV-Program Stage 3}

Source of funds obtained from the capital Saras saving with a margin of $0.20 \%$ per month, and capital investments in Sharia BPD with a margin of $1.40 \%$ per month (decline). And a margin based on the proportion of each source of funds, then the value of the average margin equivalent to the interest rate of $8.11 \%$ per year.

Table - 17

NPV Program Stage 3

\begin{tabular}{|l|l|l|l|}
\hline Years & FV & P/F (8,11,n) & PV \\
\hline 0 & - & & $(851,148,000)$ \\
\hline 1 & $261,790,676$ & 0.9250 & $242,152,138$ \\
\hline 2 & $261,790,676$ & 0.8556 & $236,032,955$ \\
\hline 3 & $261,790,676$ & 0.7914 & $227,734,834$ \\
\hline 4 & $261,790,676$ & 0.7320 & $217,998,921$ \\
\hline & & & $72,770,848$ \\
\hline
\end{tabular}

The calculations show NPV third stage of the program is more than zero, i.e.Rp72,770,848 so the investment is feasible. Based on the analysis performed on the three stages of the program, each stage shows NPV value greater than zero, so the investment/ lending to each stage of the program is feasible.

c. Internal Rate of Return (IRR)

IRR method is a method of investment appraisal to find the interest rate (discounted rate) that equates the present value of net cash flow (present value of proceeds) and investment (initial outlays) obtained when the IRR NPV equal to zero.An investment is acceptable if the IRR is greater than the interest rate used as capital costs and rejected if the IRR is less than the capital employed.

\section{IRR-Program Stage 1}

NPV calculation formula, which is done by trial and error to produce an IRR of 16:36\% value for the program's first phase.The IRR value is far above the level of margin at $2.40 \%$ 
Published by European Centre for Research Training and Development UK (www.eajournals.org)

investment that uses funding from Saras deposits and Wadiah deposits. Thus the investment is feasible.

\section{IRR-Program Stage 2}

NPV calculation formula that is done by trial and error on the second phase of the program resulted in the IRR of $16.15 \%$, IRR is above the level of investment margins on average by $4.51 \%$, which uses funding from Sarasdeposits and Mudharobah deposits.Thus the investment is feasible.

\section{IRR-Program Stage 3}

Using the formula NPV, IRR value obtained by trial and error is $8.43 \%$ for the third stage of the program.The IRR value is above the level of investment margin amounted to an average of 8.110 which uses funding from saras savings and investment capital BPD Sharia, so the investment is feasible.

\section{CONCLUSIONS AND SUGGESTION}

\section{Answers to the Research Questions \\ BMT DI capability as program implementers KPRS Micro Subsidized}

BMT DI is an Islamic MFIs that have a legal basis in the form of Cooperative. In accordance UU No. 25 of 1992 concerning Cooperative, that the activities of Member Meeting is an element of the highest authority within the institution. The implementation of the Annual Member Meeting which has been done routinely show that the activity has functioned effectively in creating an internal management system. Through reports and minutes of the RAT is implemented, there are known monitoring reports, reports of executives/ managers, legalization plan of activities and budget, supervisors, administrators/managers as well as report on realization of activities and budget, which indicates planning, organizing, actuating and controlling.BMT DI management conducted by the cooperative members showed their sense of belonging and concern over the development of the institution.In the management structure is also seen their quality of good human resources, which generally has the background and formal education is also equipped with a variety of business related training run.

In carrying out its business, the BMT DI also do a variety of activities and cooperation with external parties, indicating the formation and expansion of the network (networking), thus giving an opportunity for BMT DI to gain greater access again.In addition, there are activities that are social institutions, which the corporation's business is usually called corporate social responsibility (CSR).In accordance with the meaning of 'BaitulMaal' which translates loosely as 'treasure house', that there are social activities, which is done by using funds from zakat, infaq and shadaqah collected from the community or it can also come from funds infaq obtained from penalties for late payments from borrowers.

The use of Islamic financial system which is managed either through the provision of various facilities, services and financing schemes as well as their approach to the public through a variety of social and religious activities led to BMT DI easier offer a product for savings and loans that are offered to the public in an effort to collect and channel the funds to earn trust is better than the majority of local people who embraced Islam. 
Results of management that has been done indicates progress on capital owned by BMT DI, which is experiencing an increasing trend in the last three years.An assessment of the financial condition performed using financial ratios and measured using methods Pinbuk also shows that the financial condition of BMT IN predicate healthy enough. Various descriptions proved ability BMI DI, both institutionally and financially to be able to implement Sharia Micro Subsidized KPRS program.

\section{MBR Characteristics and the Filing of the Terms of Existing}

MBR which utilize Micro KPRS program Subsidized sharia consists of workers, peasants, merchants to civil servants, with the majority working in the informal sectors. The MBR majority have incomes of up to one million rupiah.Only a small portion MBR which has a basic educational background or lack of it, most of the other MBR has a high school education up to undergraduate level.Age largely MBR included in the productive age category.As well as from local authorities, given the housing affairs is obligatory for local governments.

\section{FURTHER RESEARCH SUGGESTIONS}

There are some things that still require further research, namely:

1. MFI development that relies on trust can cause MFIs do not have widespread outreach, so that fewer MBR can be served.Therefore, it is necessary to do research on the use of trust as the basis for the development of MFIs to provide access to credit for MBR widely.

2. Subsidies were carried out in the credit program impacts are positive or negative, so that the necessary research on the extent of subsidies provides positive benefits to the group where such benefits are positive.

3. Need to develop mechanisms and institutions that subsidization is not associated with the project.

\section{Suggestion for Decision Makes}

Implementation of the program of subsidized housing loans can work better with the participation of local government, among other things:

1. Provision of proper data, which can be used as a basis on who will get the subsidy.

2. Cooperation in disseminating the program as well as the technical requirements of the building to the public.

3. Ease of or reduction in the manufacture Building Permit (IMB) for the MBR, as its authority.

4. A guide in the implementation of program improvement / construction of the house, so that its implementation is integrated with environmental quality improvement programs in the regions, to further improve environmental quality.

5. Developing the land policy for the MBR, to acquire land at an affordable price. 


\section{REFERENCES}

Arsyad, Lincolin. 2008. LembagaKeuanganMikro: Institusi, KinerjadanSustainabilitas. Yogyakarta: PenerbitAndi

Barney, Jay B.1997. Gaining and Sustaining Competitive Advantage.Massachusetts: Addison-Wesley Pub. Co.

Chotim, EE danHandayani, A.D.Desember 2001.LembagakeuanganMikroDalamSejarah, JurnalAnalisisSosial, Volume 6 Nomor 3.

Ferguson, Bruce.April 1999. Micro Financing of Housing, Journal of Environmental and Urbanization Vol. 11, No. 1.

Francis, Jack Clark. 1983.Management Investment, New York: McGraw Hill Book, Company.

Holloh, Detlev.2001. Promotion of Small Financing Institution, Profil MicroFinance Institution Study, by Bank Indonesia, profit \& GTZ.

Kodoatie, Robert J. 1995. AnalisisEkonomiTeknik. Edisi I.Yogyakarta: Andi

Kotler, Philip.2000. ManajemenPemasaran. PT. Prehalindo.

Laurens, Joyce Marcella.2004. ArsitekturdanPerilakuManusia. Grasindo.

Mahmud, Syamsuddin. 1986. Dasar-dasarIlmuEkonomidanKoperasi. Intermasa.

O. Gill, James danChatton, Moira. 2005.MemahamiLaporanKeuangan. PPM.

Suyatno, Thomas. 1988. Dasar-dasarPerkreditan.Jakarta: GramediaPustakaUtama.

Siahaan, Hotman M. 2002.MetodePenelitianKualitatif, PerspektifMikro. Surabaya: InsanCendekia.

Subagyo, Pangestu. 2003.StatistikaDeskriptif. Yogyakarta: BPFE UGM.

Sugiyono, 2007. MetodePenelitianAdministrasi. Alfabeta

Widayat\&Amirullah. 2002.RisetBisnis. Yogyakarta: Grahallmu

\section{Regulation}

UU No. 25 of 1992 concerning Perkoperasian

Permenpera No: 06/Permen/M/2006, about Construction/Repair Housing Governmental via Credit/Microfinance with Support Facility Housing Subsidy.

Permenpera No: 06/Permen/M/2007, On the Provision of Housing and settlements with the Housing Subsidy Support Facility through KPRS / KPRS Micro Subsidized Sharia. 